\title{
Implementation of Sharia Regulation for Minorities in Nanggroe Aceh Darussalam
}

\author{
Ernawati ${ }^{1}$, Ritta Setiyati ${ }^{2}$ \\ \{ernawati@esauggul.co.id ${ }^{1}$, ritta.setiyati@esauggul.co.id ${ }^{2}$ \}
}

Faculty of Law, Universitas Esa Unggul, Jakarta Indonesia ${ }^{1}$, Faculty of Economics and Business, Universitas Esa Unggul Jakarta Indonesia ${ }^{2}$

\begin{abstract}
The implementation of Islamic Shariah is not something new in Indonesia, especially in Aceh which has a long history of the entry of Islam and the application of its Shariah in Aceh. In 2001, when the regional autonomy was rolled out in all regions of Indonesia, Aceh has issued Law no. 18 of 2001 on the Status of Special Autonomy for Aceh Province by declaring the implementation of Shariah in Aceh. Moreover, through this law gave birth to another organic regulation that regulates Islamic Shariah in the operational level in Aceh called qanun. Implementation of qonun is also applied to those who live in the region of Aceh whether it is the majority of Muslims and religious minorities who are non-Islam. In order to achieve the expected results more focused, the authors use qualitative methods with the historical and sociological approach. In order for the sample of the population to be less extensive, the author narrows the area to be studied in the city of Lhokseumawe from enforcement as well as the implementation of the Shariah (qonun) regulation for the Acehnese people of Islamic nuance, and also measures how effective a law is applied to non-Muslims as a minority community in the province of Aceh against the implementation of the Islamic Shariah law.
\end{abstract}

Keywords: Law Effectiveness, Islamic Shariah Law, Minority.

\section{Introduction}

In a tremendous hadih maja (proverb) in Aceh mentioned, Islam and customs in Aceh are like substances with nature (agama ngen adatlagee substance ngen sifet). This expression wants to show the inseparability between Islam and the prevailing customs in the Acehnese society. In Aceh's history, Islam is the only religion recognized by the kingdom. Even Islam is integrated into the life of the government of the kingdom of Aceh in the 17th century [1]. Amirul Hadi calls this integration a "politico-religious unity" which means a combination of Islam as a culture and politics in upholding the Islamic community (ummah). In this position, Islam becomes the glue that unites the various nations of Islam in politics and commerce in Aceh [2].

In 2001, when the regional autonomy was rolled out in all regions of Indonesia, Aceh issued Law no. 18 of 2001 on the Status of Special Autonomy for the Province of Nanggroe Aceh Darussalam. In this law, the announcement contained in the previous law is further narrowed, among others by establishing local regulations in Aceh called qanun and the recognition of the Syar'iyyah Court as part of the judicial system in Indonesia. This law later became the basis for the birth of several qanuns of the implementation of Islamic Shari'ah in Aceh. After the issuance of Law no. 18 of 2001, the government of Aceh at that time under the leadership of Governor Abdullah Puteh declare the implementation of Islamic Shari'ah in Aceh. The declaration was 
made at the Baiturrahman Great Mosque in Banda Aceh as a symbol of Acehnese support for the program [1]. After Law no. 11 of 2006 on the Government of Aceh, Law no. 18 of 2001 mentioned above is no longer valid. This law confirms the inevitability of the birth of other organic legislation governing the Islamic Shariah in the operational level in Aceh called qanun. Qanun was born through legislation process in DPRA as well as other regional regulation. Qanun is then the law and the law of formal law in the Islamic law of Aceh. In general, qanun contains the formalization of Islamic fiqh law that has been a long time. Not all provisions contained in Islamic fiqh can be the qanun of Sharia in Aceh; the election is tailored to the context and interests of Aceh and Indonesian national law. Likewise, some of the laws contained in Islamic jurisprudence are adapted to the development of society in Aceh [1].

Support for the implementation of Islamic Shari'ah is based on the desire to restore Islam to the glory he had ever achieved during the reign of Sultan Iskandar Muda. Although most people do not understand what Islam was like during Iskandar Muda, they believe that Islam at that time was a "Kaffah Islam" that could advance the various dimensions of life in society. It is also the second reason why the Islamic Shari'a is considered to be enforced. It is related to the position of Islam as a religion that regulates various aspects of human life. Therefore, applying Islam not only makes the rules relating to religious matters, but also relates to all the rules that exist in human life. Some even think that running Islam alone is enough because in it already there are all the systems needed to organize life and build human life. Although this view simplifies the problem, it continues to thrive in Islamic society in Aceh [1]. Feener's main argument is that the application of Sharia law in Aceh is an experiment in social engineering. For Islamists, it is usually thought that the proper application of Islamic law is the ultimate goal. However, in Aceh, sharia is considered as a tool for achieving goals, not ends. A more ambitious goal is to create a perfect society, based on a 'Kaffah Islam' and inhabited by perfect people [3].

Against the counter-formalization group of Islamic Sharia, the great support for the implementation of Islamic Shari'a in Aceh is generally done by people directly involved in Islamic organizations. This group is indeed one of the strong majority in Aceh because it dominates almost all elements of society. As an area inhabited by the majority of Muslims, Aceh is indeed familiar with well-based religious organizations labeled social organizations or educational institutions. However, this does not mean that no other civil element has different ideas and views on Islamic law. Some circles from academics and non-governmental organizations have other views on the existence of Islamic Shari'ah in Aceh. This group is categorized as a counter-Islamic Shari'a group.

The rejection of the formalization of Islamic Shari'a is not done explicitly on behalf of the organization or representing a special group. It seems to be based on the spiritual, social reality in Aceh, the rejection of the Islamic Shari'a is the same as rejecting Islam. In this context, a person who does so will get social sanction either in the form of an allegation of being out of religion or having become a foreign agent aimed at destroying Islam. It is certainly not wanted by many people as he thinks of his social life and his career further. However, someone living in a society has a relationship with the surrounding community. Therefore, the rejection of Islamic Shari'ah in Aceh is conducted in a language that does not directly reveal the controversy and negation to Islam as a whole.

Some groups who reject the formalization of Islamic law in Aceh can be divided into two forms of rejection. The first group is those who do not agree to make Islam a religion of government. This group consists of some campus academics and several NGOs working on women and human rights issues. They consider the application of Islamic Sharia as implemented in Aceh has stepped over the Constitution because, as a unitary state, there is no difference between one region and another in Indonesia. The specialization of Aceh that implements 
Islamic law is a mistake made by the government. Another reason, the application of Islamic law in Aceh is Jakarta's policy to resolve the conflict in Aceh. So, there is no Islamic shari'a as a religious formulation given by the government to Aceh. There is only a tactic to reduce the problem of rebellion in Aceh.

The second group is those who reject the form of formalization as it does today. At the level of the policy of the application of Islamic Sharia by the state, they agree. While acknowledging that there is a political process, granted by the government is seen as an opportunity for the people of Aceh to uphold Islamic values. However, they disagree with what is happening today, with qanuns that are illogical and only take care of the private matter of society. This group consisted partly of academic campus and religious organization activist in Aceh. They offer alternative discourses to make Islam better, such as Islam which ensures an egalitarian and just life of society. One thing that this group always conveyed is how to see Islam not only in the level of private laws, but also in the wider social dimension and dimension of morality [1]. The tension in Indonesian Islamic legal discourse between middle-class conservatism, similar to that seen in many Muslim Majority countries, and more specific Indonesian legal innovations are also seen in chapters relating to women, marriage law, and divorce [3].

The enforcement of Islamic Shariah in Aceh has not escaped the public's comments and concerns. Not only from the experts from Indonesia, but attention is also given by various circles in other parts of the world at that time. Attention is a comment and their response to the implementation of Islamic law and some critics given. Most, of course, assume that what happens in Aceh is a policy that is contrary to the values of human rights and democracy upheld so far. All the nations of the world are moving towards an improvement of life that upholds human rights and democracy for a better life together. Therefore, the enforcement of Islamic law in Aceh which emphasizes rules such as stoning and flogging is part of the rise of Muslim extremists who will continue the violence in the form of terrorism as happened lately [1].

Aceh as one part of NKRI (Unitary State of the Republic of Indonesia), must automatically submit to and follow the system and principles of Indonesian legislation. One of the principles adopted in the legal system in Indonesia is the principle of positivism, which in principle states that there is no law outside the law. Then in the legal treatment, Aceh gets a special treatment, which is given the authority to apply a legal system that is lex specialist (the law that applies specifically), where with the principle, it will deny a provision or legislation of a general nature, which apply to all other parts of Indonesia.

Following the release of the legality of the Government towards the implementation of Islamic Shari'a in Aceh, there have been several issues concerning how its application, because the earlier Islamic countries can not be used as a reference in its implementation, among one reason, is the different socio-cultural. Until now there has been no ideal example in a country that implements Islamic Shari'a [4].

The implementation of Islamic Shariah in Aceh is for the observers of national law mentioned as the first event after independence, where there is a territory within the power of Indonesia to apply a legal system that is relatively different from national law. The consequence is that the claim to determine an area of Islamic territory with the formalization of shari'a as positive law is a contradiction [4].

Moving from this description of the implementation of Islamic Shari'ah in Aceh known as the implementation of Islamic Shari'a in Aceh in kaffah is one interesting phenomenon to be observed about its application in society. This study will provide descriptions and seek answers to the question "How do minority groups in Nongroe Aceh Darussalam apply Islamic Shariah legislation in their daily lives? Through Effectiveness theory, researchers try to study and 
discuss the implementation of Islamic Sharia for minorities in Aceh through qanun-qanun which has been enacted in Nanggroe Aceh Darussalam.

This research is aimed to know the perception and description in general to some people of Aceh, especially the minority in the application of Islamic Shari'ah applied for the minority in this case which is not Moslem in Aceh.

\section{Methodology}

Methodologically, the approach in this research is qualitative research. Therefore, this approach is intended to know how far the application of Islamic law in the region of Aceh, especially in the minority who are not Muslim (Christian, Hindu, Buddhist, and Konghuchu). This research covers field research and library research from Data collection in this research is by observation method, interview, and literature study. The subject of this research was conducted in Lhokseumawe Aceh.

\section{Results and Discussion}

\subsection{Profile of Aceh Province}

Nanggroe Aceh Darussalam is a province of Indonesia. Nanggroe Aceh Darussalam is located at the northern tip of the island of Sumatra and is the most western province in Indonesia. The capital is Banda Aceh. The population of this province based on 2016 is about 5.096.248 people with a male population of $2,545,113$ people and the female population as many as 2551.135 inhabitants [14].

With the enactment of the Law of the Republic of Indonesia Number 44 Year 1999 concerning the Implementation of the Privileges of Aceh, which is outlined by the Provincial Regulation of the Special Province of Aceh, No. 5 of 2000 on the Implementation of Islamic Shari'a in Nanggroe Aceh Darussalam and Law Number 18 Year 2001 regarding Special Autonomy for Aceh, the Aceh region has its own distinctive areas of religion, customs and education.

Nanggroe Aceh Darussalam is the land closest to the epicenter of the 2004 Indian Ocean earthquake. After the earthquake, tsunami waves hit most of the province's west coast. About 170,000 people died or disappeared from the disaster. This disaster also encouraged the creation of a peace agreement between the government of the Republic of Indonesia and the Free Aceh Movement (GAM).

The name of Aceh Province was used since 2009 based on Aceh Governor Regulation number 46 of 2009, previously Aceh Province called by the Special Region of Aceh (19592001) and Nanggroe Aceh Darussalam (2001-2009). The capital of Aceh Province is Banda Aceh. Aceh is one of the areas in Indonesia that attracted the attention of the people in the country and abroad. The Aceh tribe has its uniqueness, especially the mixed integration of indigenous peoples with Indian, Chinese, Arab and European migrants, resulting in a mixture of ethnicities that eventually became an ethnic Aceh. Aceh is a predominantly Muslim province and Aceh also has a special one of which is Shari'ah Islam. This country was dubbed the Veranda of Mecca. In addition Banda Aceh City as the capital of Aceh Province which has a population of various faiths and is one of the oldest Islamic city in Southeast Asia [15]. 
The city of Lhokseumawe is a division of North Aceh Regency and is located on the east coast of Sumatra Island. The position of Lhokseumawe City lies between Banda Aceh City and Medan, making this city very strategic as distribution and trade channel in Aceh.

Number of adherents of religion in Lhokseumawe City According to each sub-district during 2016, Islam is 203,783 adherents, Catholic 185 adherents, Protestant 766 adherents, Hindu 10 adherents, Buddhist 718 adherents. More details see the following table [14]:

Table 1 Number of Adherents of each Religion Year 2016

\begin{tabular}{cllllll}
\hline No & districts & Islam & Catholic & Protestant & Hindu & Buddha \\
\hline 1 & Blang Mangat & 24.644 & 3 & 61 & 0 & 1 \\
2 & Muara Dua & 51.445 & 6 & 20 & 1 & 46 \\
3 & Muara Satu & 37.801 & 18 & 119 & 1 & 1 \\
4 & Banda Sakti & 89.893 & 158 & 566 & 8 & 671 \\
& Total & 203.783 & 185 & 766 & 10 & 718 \\
\hline
\end{tabular}

Source: Central Bureau of Statistics of Lhokseumawe City, Lhokseumawe City In Figures 2017, p. 177. see also: Office of the Ministry of Religious Affairs of Lhokseumawe City

Table 2. Number of Houses of Worship of Each Religion Year 2016

\begin{tabular}{cccccccc}
\hline No & Districts & Mosque & Mushalla & Meunasah & Church & Temple & Vihara \\
\hline 1 & Blang Mangat & 13 & 10 & 22 & 0 & 0 & 0 \\
2 & Muara Dua & 12 & 21 & 17 & 0 & 0 & 0 \\
3 & Muara Satu & 8 & 45 & 11 & 0 & 0 & 0 \\
4 & Banda Sakti & 17 & 17 & 18 & 3 & 0 & 1 \\
& Total & 50 & 93 & 68 & 3 & 0 & 1 \\
\hline
\end{tabular}

Source: Central Bureau of Statistics of Lhokseumawe City, Lhokseumawe City in Figures 2017, p.178. see also: Office of the Ministry of Religious Affairs of Lhokseumawe City

\subsection{The effectiveness of the Law}

In the context of law, according to Hans Kelsen, the definition of the effectiveness of the law is: Do people in fact act in a way to avoid sanctions threatened by legal norms or not, and whether the sanctions are implemented or not. Anthony Allot argues about the effectiveness of the law, namely: The law will be effective if the purpose of existence, in general, can make what is designed can be realized. If failure, then there is the possibility of easy rectification if there is a need to implement or apply the law in a different new atmosphere, the law will be able to solve it [5].

Said by Soerjono Soekanto, that an attitude of legal behavior is considered effective, if attitudes, actions or other behavior toward the desired goal, meaning that if the other party obey the law. The law can be effective if the role of law enforcement officials is closer to what the law seeks and will be ineffective if the role of law enforcement is far from what the law intends [6].

\subsection{Local Sharia law}

Islamic law in its development serves as one of the basic materials of national law other than customary law and western law. In the period of Dutch colonialism applied a law called Indische Staatsregeling S 1855-2, which contains the law of the Dutch East Indies. The law accommodates 3 (three) existing legal systems, namely Islamic law, customary law, and western law. After the proclamation of Indonesian independence on August 17, 1945, national law still built three sources of the law, so it is said that the national law in the form of positive law still 
consists of three elements. It's just the principle of its formation based on Pancasila and the 1945 Act [7].

One of the most important breakthroughs for the Special Region of Aceh during the reform era was the issuance of Law No. 44/1999 on the Implementation of Aceh Province's Privileges. The birth of this Law has covered the vacancy of the privilege of Aceh province that was once based solely on moral commitment with a Decree No.01/Missi/1959. Now the moral support has been strengthened by the guarantee of the Law, the guarantee of positive law which has legal legitimacy.

If the previously mentioned laws of law as part of private law apply to Muslims throughout Indonesia, then Law No. 44 of 1999 is treated explicitly for the Provincial Territory of Aceh to establish regional privileges in four areas: the administration of religious life, the dedication and role of Ulama in determining regional policy.

As a follow-up and the elaboration of Law Number 44 the 1999, several Regional Regulations have been issued, one of which is Regional Regulation No. 5/2000 on the implementation of Islamic Shariah. The implementation of Islamic Shari'ah in Nanggroe Aceh Darussalam should be more profitable and provide many benefits to all parties both for the Aceh region in particular and Indonesia in general. It is because Islamic shari'ah is not only about the dimension of tauhid, but also another social dimension.

In article 18, paragraph 1 stated that "the regional government together with the MPU need to formulate the provisions concerning the subjects and events of the implementation of Qadha, Jinayat, Munakahat and Mawaris in line with the Islamic Shari'ah."

Implementation of qadha so far, especially about some parts of private law that became compensation has become routine work of the Religious Court for a long time. The existence and competence of the Religious Courts have also been strengthened by the birth of Law No.7 of 1989 on the religious court.

\subsection{Minorities}

According to the theme studied here, the minority is aimed at non-Muslims (Christians, Hindus, Buddhists, and Konghuchu) who live in Muslim-majority areas that apply Islamic law in the region. Christianity is the second largest religious minority in Aceh shared by 50,309 Protestant Christians. In addition, as many as 3,315 people in Aceh are Catholic. The total number of Acehnese who is Christians and Catholics is about 53,624 people or about $1.19 \%$ of the 5,096,246 inhabitants of Aceh (aceh.bps.go.id). While the number of churches recorded as many as 154 churches standing throughout Aceh (2016).

As it is seen that in Aceh there are various religions, in religion especially Islam teaches peace, the life of mutual respect, and mutual help-help. Islam emphatically gives freedom in religious and religious matters. Islam brought by Prophet Muhammad SAW, is indeed Rahmatan lil'alamin [8].

Minorities in classical literature are often referred to as ahl al-dzimmah or ahl al-mu'anadah and are often abbreviated as dzimmi. What is meant by this term is that all non-Muslims who remain obedient and faithful to the rules of the Islamic state in which they live, regardless of where they came from or where they were born. Against this group of countries, Islam assures to protect them in their lives, in their culture, wealth and trust and honor [12][13].

Among the rights of protected minorities is freedom of religion and worship. Qur'an is explicitly mentioned that everyone has the right to embrace their respective religions and beliefs. A dzimmi should not be forced to convert to Islam in any way. The essence of this doctrine is evident in verse in the Qur'an: There is no compulsion to enter the religion (Islam) it is clear the right path rather than the wrong path (QS. Al-Baqarah: 256). 
Creating a peaceful life, then every religion teaches the meaning of life in harmony. Harmony is the condition and the process of creating interaction patterns that vary among autonomous units. Harmony reflects a reciprocal relationship characterized by mutual acceptance, mutual trust, mutual respect and appreciation, and mutual understanding of mutuality [9].

The basic guidelines of religious harmony in Indonesia, as described by the government through the Ministry of Religious Affairs by programming 3 (three) forms of harmony, namely: 1) Internal harmony of the faithful 2) Harmony between religious communities 3) Harmony with the government [10].

The internal harmony of the religious community is the creation of harmony among the schools, ideologies, schools within a particular religion or people or religious community. Harmony among religious people is the harmony among the followers of different religions. While inter-religious harmony with the government is the creation of harmony and harmony between religious leaders and the government with mutual understanding and appreciate their respective duties in order to build a religious people, so hopefully will create a just and prosperous society and obedient to carry out religious orders [11].

Since the issuance of Law No. 4/1999 on the Implementation of Specialties of Aceh Special Region, the opportunity to implement Islamic Shari'a in this area is beginning to open. This opportunity, more explicitly mentioned in the Regional Regulation No. 5 of 2000 on the Implementation of Islamic Shari'ah in Aceh, although in many cases polemic and controversy still occur [12].

Syariat Islam Aceh is formally implemented after the issuance of Law no. 44 The year 1999. About the Implementation of Special Feature of the Special Province of Aceh and Law no. 18 of 2001 on Special Autonomy for the Special Province of Aceh as the Province of Nanggroe Aceh Darussalam. Aceh Province is a province that has a regional regulation (qanun) on the implementation of Islamic law as a whole, qanun not only regulate family law (marriage and inheritance) and economy but also regulate jinayah (criminal law) listed in Qanun. 5 years 2000 Article 5 paragraph (2) and also the law of diyani (worship and morals) [16].

The legality of the government to implement Islamic Sharia in Aceh was responded by the local government by issuing some local regulations in the implementation of Islamic Shari'ah in Aceh. From the regulation, it was further developed into regional regulations concerning the Islamic Shari'a regulation which in turn gave birth to the Aceh Qanun [16].

Another fundamental problem faced by the proponents of the formalization of Islamic Shari'ah in Indonesia is the problem of definition or definition of Islamic Shari'a itself because, without a clear defining process, it can and in most cases will collide with the principles of human rights. The three aspects of human rights most concerned with the application and formalization of Islamic law are restrictions on freedom of religion, discrimination against women, and discrimination against non-Muslims [13].

Some have classified the controversy over the Sharia law in three groups. First, the support; second, the rejected and the third who has no attitude whether to support or refuse. Then the third group is outside of this study because it is not yet part of the personal view. In another view, there is a grouping of this controversy between religious and nationalist circles. The supportive religious and nationalist groups rejected. Religious circles are based on students (santris) who are non-santri but have a high concern for Islam [17].

The controversy in responding to the Shari'ah law is not an attitude that has arisen recently, but it has a backward root. The difference given Islam has implications for the acceptance of the existence of sharia law. Some see Islam as a system of life, and some are seeing it solely as 
a religion, as with other religions. For those who view Islam as a religion alone, Islam only regulates ritual and spiritual issues [17].

Views that do not want intervention in religion and state or vice versa is a view that is then called secular, which is to separate between religion and the State. In Indonesia, although some try to be secular, this group is not very influential, because the State is not a secular state. As mentioned above, religious and nationalist groups differ given the existence of the Shari'ah law. Nationalists do not want religious symbols, while religious people can not relinquish religion from their lives, whether symbolically or substantially [17].

The enforcement of Islamic law in the present province of Aceh is apparently still in the corridor of the trilogy of religious harmony, namely inter-religious harmony, religious harmony, and harmony among religions with the Government. It is also in line with the basic guidelines in religion for the Indonesian nation is regulated in Article 29 of the 1945 Constitution on the freedom to practice their religious teachings and beliefs [18].

The implementation of Islamic Sharia in Aceh is regulated in Article 127 paragraph (1) stating that "the Government of Aceh and the district/municipality government are responsible for the implementation of Islamic Shari'ah". Then in paragraph (2) it states that "Aceh government and district /city government guarantee freedom, foster harmony respect religious values adopted by religious people and protect fellow religious people to practice worship by the religion it embraces". In the implementation of Islamic Shari'ah this required a budget. Therefore Article 127 paragraph (3) stipulates that "the Government, the Aceh Government and the district/municipality governments allocate funds and other resources for the implementation of Islamic Shari'ah". What about non-Muslims residing in Aceh? In this case, described in article 126 paragraph (2) states that "everyone who resides or is in Aceh shall respect the implementation of Islamic law". It means that although non-Muslims do not apply Islamic law, they must respect the implementation of Islamic Shariah in Aceh [19].

Qonun related to the implementation of Islamic Shari'ah in Aceh that adheres to the principle of Islamic personality, meaning that qonun syariat as mentioned above apply only to Muslims only, while non-Muslims in general (Protestant, Catholic, Hindu and Buddhist, Trust) is not included in it, let alone forced to implement it, certainly not possible at all. Thus, for the non-Muslim population in Aceh there is no difficulty to remain in the province of Aceh, as they remain subject to the Criminal Code as a national law applicable, in addition to adhering to nonShari'ah qonun [18].

\section{Conclusion}

The enforcement of Islamic law in the present province of Aceh is apparently still in the corridor of the trilogy of religious harmony, namely inter-religious harmony, religious harmony, and inter-religious harmony with the Government. It is in line with the basic guidelines in religion for the Indonesian nation is regulated in Article 29 of the 1945 Constitution on the freedom to practice their religious teachings and beliefs. It can be seen from the implementation of Islamic Sharia in Aceh as stipulated in Article 127 paragraph (2) stated that "Aceh Government and district/city government guarantee freedom, foster harmony respect religious values adopted by religious people and protect fellow religious people to worship by the religion they embraces ".

In connection with the implementation of Islamic Shari'ah in Aceh, it adheres to the principle of the personality of Islam, in this case, described in article 126 paragraph (2) states 
that "everyone who resides or resides in Aceh shall respect the implementation of Islamic Shari'a" means that the qonun of Shari'a as mentioned above is only applicable to Muslims only, while non-Muslims in general (Protestant, Catholic, Hindu and Buddhist, even Believers) are not included in it, this means that although against non-Muslims apply Islamic law, but they must still respect the implementation of Islamic Shari'ah in Aceh.

\section{References}

[1] Shadiqin, S. I. "Islam dalam Masyarakat Kosmopolit: Relevankah Syariat Islam Aceh untuk Masyarakat Modern?,” Kontekst. J. Penelit. Sos. Keagamaan, vol. 25, no. 1, 2010.

[2] Hadi, A. Islam and state in Sumatra: A study of seventeenth-century Aceh, vol. 48. Brill Academic Pub, 2004.

[3] Feener, R. M. Shari'a and social engineering: The implementation of Islamic law in contemporary Aceh, Indonesia. OUP Oxford, 2013.

[4] Bahri, S. "Pelaksanaan Syari'at Islam di Aceh sebagai Bagian Wilayah Negara Kesatuan Republik Indonesia (NKRI),” J. Din. Huk., vol. 12, no. 2, 2012.

[5] Salim, H. S., and E. S. Nurbani, "Penerapan Teori Hukum Pada Penelitian Tesis dan Disertasi," Raja Graf. Persada, Jakarta, 2013.

[6] Soekanto, S. Faktor-faktor yang mempengaruhi Penegakan Hukum. Rajawali, 1983.

[7] Sirajuddin , M., and Zubaedi, Legislasi Hukum Islam di Indonesia. Pustaka Pelajar, 2008.

[8] A. Kholil, Agama kultural masyarakat pinggiran. UIN-Maliki Press, 2011.

[9] H. M. Lubis, "Ridwan, dkk.(Eds.), 2004," Buku Penuntun Kerukunan Hidup Umat Beragama.

[10] Naim, S. Kerukunan antara umat beragama. PT. Gunung Agung, Jakarta, 1983.

[11] D. A. R. Indonesia, "Pedoman Dasar Kerukunan Hidup Beragama," Jakarta Proy. Pembin. Kerukunan Hidup Beragama Dep. Agama, 1984.

[12] Muhammad, R. A. Revitalisasi syari'at Islam di Aceh: problem, solusi, dan implementasi. Kerjasama IAIN ar-Raniry, Nanggroe Aceh Darussalam dengan Penerbit Logos Wacana Ilmu, 2003.

[13] Yusdani,Y. "Formalisasi Syariat Islam dan Hak Asasi Manusia di Indonesia," AlMawarid, vol. 16, 2006.

[14] BPS, Kota Lhokseumawe dalam Angka 2017. .

[15] Umartha, B. A. Membangun Karakter Masyarakat Aceh Menyikapi Kehidupan Global.

[16] Berutu, A. G. "Implementasi Qanun Maisir (Judi) Terhadap Masyarakat Suku PakPak Di Kota Subulussalam-Aceh,” ARISTO, vol. 4, no. 2, pp. 31-46, 2016.

[17] Abra, E. H. "Kontroversi Legalitas dan Penerapan Perda Syariah Dalam Sistem Hukum Indonesia," J. Dimens., vol. 3, no. 3, 2016.

[18] Kamarusdiana, K. "Qânûn Jinâyat Aceh dalam Perspektif Negara Hukum Indonesia," AHKAM J. Ilmu Syariah, vol. 16, no. 2, pp. 151-162, 2016.

[19] Ernawati, "Kewenangan Mahkamah Syar'Iyah Di Aceh Materiil Dan Hukum Formil)," vol. 11, no. September 2014, 2006. 